\title{
Astrocytes Give Rise to New Neurons in the Adult Mammalian Hippocampus
}

\author{
Bettina Seri, ${ }^{1}$ Jose Manuel García-Verdugo, ${ }^{2}$ Bruce S. McEwen, ${ }^{1}$ and Arturo Alvarez-Buylla ${ }^{3}$ \\ 1 The Rockefeller University, New York, New York 10021, 2University of Valencia, Burjasot-46100, Valencia, Spain, and \\ 3University of California, San Francisco, San Francisco, California 94143-0520
}

\begin{abstract}
Neurogenesis in the dentate gyrus of the hippocampus persists throughout life in many vertebrates, including humans. The progenitors of these new neurons reside in the subgranular layer (SGL) of the dentate gyrus. Although stem cells that can self-renew and generate new neurons and glia have been cultured from the adult mammalian hippocampus, the in vivo primary precursors for the formation of new neurons have not been identified. Here we show that SGL cells, which express glial fibrillary acidic protein and have the characteristics of astrocytes, divide and generate new neurons under normal
\end{abstract}

conditions or after the chemical removal of actively dividing cells. We also describe a population of small electron-dense SGL cells, which we call type D cells and are derived from the astrocytes and probably function as a transient precursor in the formation of new neurons. These results reveal the origins of new neurons in the adult hippocampus.

Key words: neurogenesis; hippocampus; neural stem cells; astrocytes; adult mammalian brain; dentate gyrus; subgranular layer
The identification of stem cells is essential to understand how tissues continue to generate new cells in the adult organism. Of particular interest is the adult vertebrate brain, in which we now know new neurons continue to be produced throughout life (Altman, 1969; Kaplan and Hinds, 1977; Goldman and Nottebohm, 1983; Garcia-Verdugo et al., 1989; Lois and AlvarezBuylla, 1994). Neurogenesis in the adult mammalian brain has been described in two restricted germinal zones: the subgranular layer (SGL) of the dentate gyrus of the hippocampus (Altman and Das, 1965; Kaplan and Bell, 1984; Cameron et al., 1993) and the subventricular zone (SVZ) in the lateral wall of the lateral ventricle (Altman and Das, 1966; Altman, 1969; Lois and Alvarez-Buylla, 1993). Cells that in vitro behave as neural stem cells have been isolated from these two regions of the adult brain (Morshead et al., 1994; Gage et al., 1995; Weiss et al., 1996; Palmer et al., 1997). Moreover, neuronal precursors have been isolated from the adult human dentate gyrus (Roy et al., 2000).

Adult hippocampal neurogenesis has been demonstrated in birds (Barnea and Nottebohm,1994), reptiles (Lopez-Garcia, 1993), rodents (Altman and Das, 1965), and primates, including humans (Gould et al., 1997; Eriksson et al., 1998). In the adult mammalian dentate gyrus, new neurons are born in the SGL and migrate a short distance to differentiate into granule cells that project an axon to the CA3 region of the hippocampus (Stanfield and Trice, 1988; Markakis and Gage, 1999). The function of

\footnotetext{
Received Feb. 14, 2001; revised May 4, 2001; accepted May 31, 2001.

This work was supported by National Institutes of Health (NIH) Grant NS28478. B.S. was supported by NIH Grant GM07524. J.M.G.-V. was supported by Fundacio La Caxia and by Comision Conjunta Hispano-Norteamericana de Cooperacion Cientifica y Tecnologica. We are grateful to Bhagwattie Haripal and D. Lucia Collado Morente for their technical assistance. We are also thankful to E. Holland and $\mathrm{H}$. Varmus for the Gtva mice and RCAS-AP plasmid and to Andrew D. Leavitt for the anti-tvaR antibody. We thank Anthony Tramontin and Thierry Lints for critical comments on this manuscript.

Correspondence should be addressed to Arturo Alvarez-Buylla, University of California, San Francisco, Brain Tumor Research Center, Box 0520, San Francisco, CA 94143-0520. E-mail: abuylla@itsa.ucsf.edu.

Copyright (C) 2001 Society for Neuroscience $\quad 0270-6474 / 01 / 217153-08 \$ 15.00 / 0$
}

neurogenesis in the hippocampus has been correlated with learning and memory (Barnea and Nottebohm, 1995; Kempermann et al., 1997; Gould et al., 1999; Shors et al., 2001). Furthermore, stress, opiate abuse, and seizures can influence the rates of cell proliferation and differentiation of new neurons in the dentate gyrus (Gould et al., 1992; Parent et al., 1997; Eisch et al., 2000)

The primary precursors in the SVZ, the other germinal region of the adult brain, have been identified recently as having the characteristics of astrocytes and expressing glial fibrillary acidic protein (GFAP) (Doetsch et al., 1999b; Laywell et al., 2000). This finding was surprising because astrocytes are considered differentiated cells belonging to the glial lineage. Another report suggested that ependymal cells correspond to the in vivo SVZ stem cells (Johansson et al., 1999); however, this conclusion is not supported by other studies (Chiasson et al., 1999; Doetsch et al., 1999b; Laywell et al., 2000).

Interestingly, astrocytes have been shown to divide in the SGL and hilus of the adult dentate gyrus, but it has been ascribed generally to a process of ongoing gliogenesis (Kaplan and Bell, 1984; Cameron et al., 1993; Palmer et al., 2000). Although earlier evidence suggested that small dark cells of undifferentiated appearance corresponded to the neuronal precursors (Kaplan and Bell, 1984), the identity of the primary neuronal precursors has not been determined.

Using an approach similar to the one used to identify the neural stem cells in the SVZ, we show here that SGL astrocytes are the primary precursors in the formation of new neurons in the adult hippocampus. We also show that the small dark cells, previously thought to correspond to the primary precursors, are derived from the dividing astrocytes and probably correspond to a transient cell type in the generation of new granule neurons. Notably, the neurogenic niche in the SGL is unique in that, unlike the SVZ or the VZ of adult birds (Alvarez-Buylla and Nottebohm, 1988; Alvarez-Buylla et al., 1998; Lim et al., 2000), it is separated from the walls of the ventricles or the ependymal layer. 
This work identifies a second population of astrocytes in the adult mammalian brain with the potential to generate new neurons.

\section{MATERIALS AND METHODS}

\section{Animal care and tissue processing}

Adult mice (2-4 months old, weighing $\geq 30 \mathrm{gm}$ ) were used for all of the experiments. Before perfusion, mice were deeply anesthetized with 1.3 $\mathrm{mg} / \mathrm{gm}$ body weight of pentobarbital (Nembutal) injected intraperitoneally. For light microscopy, animals were transcardially perfused with $10-30 \mathrm{ml}$ of $0.9 \%$ saline, followed by $30-50 \mathrm{ml} 3 \%$ paraformaldehyde (PFA) in phosphate buffer (PB), $\mathrm{pH} 7.4$, for 5 min. Brains were incubated overnight in $3 \%$ PFA. On the next day, they were transferred to Trisbuffered saline (TBS), $\mathrm{pH}$ 7.4. For free-floating immunocytochemistry, brains were sectioned frontally at $50 \mu \mathrm{m}$ with a vibrating microtome. For electron microscopy, animals were perfused with $10-30 \mathrm{ml}$ of $0.9 \%$ saline, followed by $30-50 \mathrm{ml} 3 \%$ PFA and $2.5 \%$ glutaraldehyde (Electron Microscopy Sciences, Fort Washington, PA) in PB, pH 7.4, for 5 min, and incubated overnight in the same fixative. On the next day, brains were transferred to PB, pH 7.4, cut frontally at $200 \mu \mathrm{m}$, and processed for EM (see below). For stereotaxic surgery, animals were anesthetized (0.3 $\mathrm{mg} / \mathrm{gm}$ body weight) by intraperitoneal injection of pentobarbital (Nembutal). All animal care was in accordance with institutional guidelines.

\section{BrdU and $\left[{ }^{3} \mathrm{H}\right]$ thymidine administration}

Adult CD-1 mice received a single intraperitoneal injection of 5-bromo$2^{\prime}$-deoxiuridine (BrdU) (Sigma, St. Louis, MO) at $50 \mu \mathrm{g} / \mathrm{gm}$ body weight $(10 \mathrm{mg} / \mathrm{ml}$ stock, dissolved in $0.9 \%$ saline) or a single intraperitoneal injection of $\left[{ }^{3} \mathrm{H}\right]$ thymidine at $10 \mu \mathrm{Ci} / \mathrm{gm}$ body weight (specific activity, 6.7Ci/mmol; NEN, Boston, MA). Animals were killed 2, 24, and $72 \mathrm{hr}$ later. For the cytosine- $\beta$-D-arabinof uranoside (AraC) plus procarbazol cocktail treatment (APB) experiment, adult $\mathrm{CD}-1$ mice received two intraperitoneal injections (12 hr apart) of either BrdU or $\left[{ }^{3} \mathrm{H}\right]$ thymidine at the same dosage as the experiment above. All animals were perfused $2 \mathrm{hr}$ after the last injection of DNA precursor.

\section{Anti-mitotic treatment}

CD-1 mice received a combination treatment of anti-mitotic drugs $1.5 \%$ AraC (Sigma) in $0.9 \%$ saline and procarbazol $(0.25 \mathrm{mg} / \mathrm{ml}$; HoffmannLaRoche, Nutley, NJ). The AraC was infused on the surface of the brain at the following stereotaxic coordinates: anteroposterior, 1.5; mediolateral, 0.8 relative to bregma using a micro-osmotic pump (flow rate, 0.5 $\mu \mathrm{l} / \mathrm{hr}, 7 \mathrm{~d}$; Alzet model 1007D; Alza, Palo Alto, CA). Procarbazol was administered in the drinking water. After $7 \mathrm{~d}$ of treatment, pumps were removed, as well as the procarbazol, from the drinking water. Before being killed at each time point, mice were injected twice (12 hr apart) with either BrdU for light microscopy or $\left[{ }^{3} \mathrm{H}\right]$ thymidine for electron microscopy (see above for dosage and administration regimen). Animals were perfused $2 \mathrm{hr}$ after the last injection of BrdU or $\left[{ }^{3} \mathrm{H}\right]$ thymidine at $0(n=4), 2(n=5), 4(n=5), 6(n=4), 8(n=4), 10(n=5)$ and 15 $(n=3) \mathrm{d}$. In addition, some animals were allowed to survive for $2 \mathrm{~d}$ after APB treatment termination, were injected twice ( $12 \mathrm{hr}$ apart) with either BrdU or $\left[{ }^{3} \mathrm{H}\right]$ thymidine, and allowed to survive for 30 or $150 \mathrm{~d}$.

Saline controls. Adult CD-1 mice were implanted with a micro-osmotic pump containing $0.9 \%$ saline. Mice were provided with normal drinking water. After $7 \mathrm{~d}$ of continued infusion, animals received two injections of BrdU or $\left[{ }^{3} \mathrm{H}\right]$ thymidine as described above. Two hours after the last injection of DNA, analog brains were processed for light microscopy and EM, respectively.

Intact controls. Adult CD-1 mice received two intraperitoneal injections of BrdU or $\left[{ }^{3} \mathrm{H}\right]$ thymidine as described above and perfused $2 \mathrm{hr}$ after the last injection.

\section{Immunocytochemistry}

$D N A$ denaturation for BrdU detection. Sections (either 50 or $6 \mu \mathrm{m}$ ) were incubated in $60 \%$ formamide $-2 \times \mathrm{SSC}$ at $54^{\circ} \mathrm{C}$ for $20 \mathrm{~min}$, rinsed in $2 \times$ $\mathrm{SSC}$ for $5 \mathrm{~min}$, incubated in $2 \mathrm{~N} \mathrm{HCl}$ at $37^{\circ} \mathrm{C}$ for $30 \mathrm{~min}$, rinsed in $0.1 \mathrm{M}$

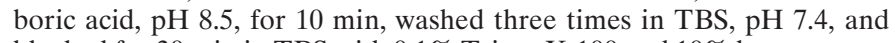
blocked for $30 \mathrm{~min}$ in TBS with $0.1 \%$ Triton X-100 and $10 \%$ horse serum. For double staining, primary antibodies from different species were incubated simultaneously, and secondary antibodies were used sequentially. Sections were incubated for $48 \mathrm{hr}$ at $4^{\circ} \mathrm{C}$ with mouse monoclonal antibody (mAb) to GFAP (Boehringer Mannheim, Indianapolis, IN) and rat anti-BrdU mAb (1:200; Accurate Chemicals, Westbury, NY). GFAP staining was revealed by rhodamine-conjugated anti-mouse IgG (1:200;
Jackson ImmunoResearch, West Grove, PA) for $2 \mathrm{hr}$ at room temperature and rinsed three times in TBS. BrdU was revealed with a biotinylated anti-rat IgG (1:200; Vector Laboratories, Burlingame, CA) for $2 \mathrm{hr}$ at room temperature, washed three times in TBS, and incubated in fluorescein-avidin (1:200; Vector Laboratories) for $1 \mathrm{hr}$ at room temperature. All sections were rinsed in TBS and mounted with Aquamount (Polysciences, Warrington, PA). Sections were analyzed with a Zeiss (Oberkochen, Germany) LSM510 confocal microscope.

Double staining with GFAP and tva receptor. Gtva mice were perfused and fixed overnight as described above. Fifty micrometer sections were blocked in $\mathrm{PB}$ with $10 \%$ horse serum for $30 \mathrm{~min}$ at room temperature, incubated $48 \mathrm{hr}$ at $4^{\circ} \mathrm{C}$ with mouse anti-GFAP (mAb 1:200; Boehringer Mannheim) and rabbit anti-tva receptor (tvaR) (1:200; gift from Andrew D. Leavitt, University of California, San Francisco) in PB with $10 \%$ horse, rinsed three times in $\mathrm{PB}$, incubated $2 \mathrm{hr}$ at room temperature with rhodamine-X anti-mouse IgG (1:200; Jackson ImmunoResearch), rinsed three times in $\mathrm{PB}$, incubated $1 \mathrm{hr}$ in biotinylated anti-rabbit $\operatorname{IgG}$ (1:200; Vector Laboratories), rinsed three times in $\mathrm{PB}$, incubated $45 \mathrm{~min}$ in fluorescein-avidin DCS (1:200; Vector Laboratories), rinsed three times in $\mathrm{PB}$, and mounted with Aquamount (Polysciences). Sections were analyzed with a Zeiss LSM510 confocal microscope.

\section{Retroviral injections}

Adult Gtva mice anesthetized as described above were stereotaxically injected with $200 \mathrm{nl}$ of RCAS-alkaline phosphatase (AP) retrovirus into the dentate gyrus of the hippocampus in three locations (anteroposterior, mediolateral, and dorsoventral, respectively: 1.0, 0.6, and 1.75; 1.3, 0.7, and 1.85; and 1.5, 0.8, and 1.85). All coordinates were measured from bregma and the surface of the brain. Animals were perfused for light microscopy (as described above) at $0.5(n=5), 1(n=4), 2(n=8), 4$ $(n=5), 15(n=9)$, and $30(n=8) \mathrm{d}$ after viral injection. After overnight fixation in $3 \%$ PFA, brains were serially sectioned (50 $\mu \mathrm{m}$, frontal) and stained for alkaline phosphatase to reveal the infected cells and their progeny. Briefly, sections were incubated in PBS, pH 7.4, for $30 \mathrm{~min}$ at $65^{\circ} \mathrm{C}$ to inactivate endogenous AP activity. Sections were then allowed to cool down to room temperature in fresh PBS, incubated in AP buffer (100 mM Tris- $\mathrm{HCl}$, pH 9.5, $100 \mathrm{~mm} \mathrm{NaCl}$, and $5 \mathrm{~mm} \mathrm{MgCl}$ ) for $10 \mathrm{~min}$, and incubated in the dark in AP substrate: nitroblue tetrazolium chloride (NBT) $(10 \mu \mathrm{l} / \mathrm{ml} \mathrm{AP} \mathrm{buffer)} \mathrm{and} \mathrm{5-bromo-4-chloro-3-indolyl} \mathrm{phosphate}$ (BCIP) ( $2 \mu \mathrm{l} / \mathrm{ml}$ AP buffer) (Boehringer Mannheim). When enough precipitate developed (between 30 and $120 \mathrm{~min}$ ), sections were rinsed three times in PBS.

\section{Autoradiography and EM analysis}

Autoradiography and EM analysis were performed as described previously (Doetsch et al., 1997).

Retrovirally infected cells. The EM embedding protocol by Doetsch et al. (1997) was modified for this experiment. Briefly, adult Gtva mice were injected with the RCAS-AP virus as described above. After a 2 d survival, mice were deeply anesthetized with $1.3 \mathrm{mg} / \mathrm{gm}$ body weight of pentobarbital (Nembutal) and transcardially perfused with $30 \mathrm{ml}$ of $0.9 \%$ saline, followed by $3 \%$ PFA and $0.8 \%$ glutaraldehyde in $\mathrm{PB}, \mathrm{pH} 7.4$, for $5 \mathrm{~min}$. Brains were post-fixed in the same fixative for $2 \mathrm{hr}$ at $4^{\circ} \mathrm{C}$ and then transferred to $3 \%$ PFA overnight. Brains were serially sectioned $(50 \mu \mathrm{m}$, frontal) and stained for alkaline phosphate as described above. Sections containing alkaline phosphatase-positive cells were washed overnight in PBS at $4^{\circ} \mathrm{C}$, fixed in $1 \%$ osmium tetroxide (Electron Microscopy Sciences) containing $7 \%$ glucose for $1 \mathrm{hr}$ at room temperature, washed three times in maleic acid, and incubated $1 \mathrm{hr}$ in uranyl acetate (Electron Microscopy Sciences) (2\% solution dissolved in maleic acid). Sections were then washed three times in maleic acid, dehydrated in an ascending ethanol series, rinsed for $2 \mathrm{~min}$, two times in propylene oxide, and embedded in Durcupan (ACM; Fluka Neu-Ulm, Germany). Sections embedded in Durcupan were mounted on glass slides coated with silicone (Rain-X) and allowed to polymerize for $2 \mathrm{~d}$. Additional tissue processing was performed as described by Doetsch et al. (1997).

\section{RESULTS}

\section{Dividing cell types in the SGL}

We first characterized the dividing cell types present in the SGL. Cells were studied at the confocal microscope $2 \mathrm{hr}$ after BrdU injection. BrdU-positive cells were frequently labeled by antibodies to GFAP (Fig. 1a). A smaller proportion of the BrdU-labeled 

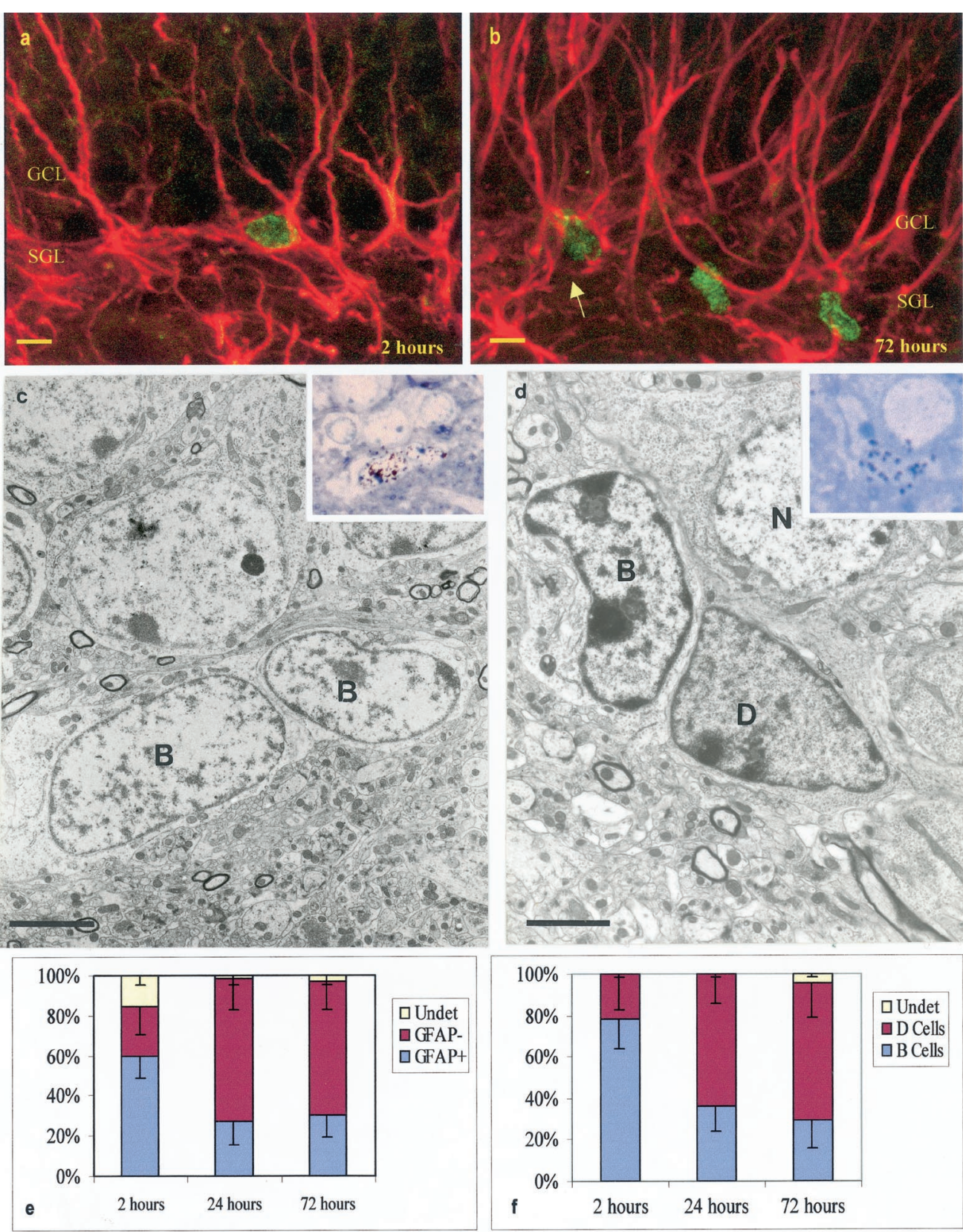

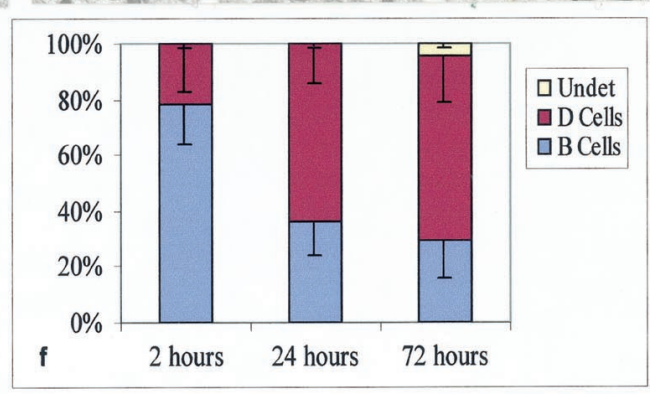

Figure 1. Dividing cells in the SGL. $a$, Confocal micrograph of BrdUlabeled GFAP-positive SGL astrocyte $2 \mathrm{hr}$ after BrdU injection. Note the BrdU-labeled nuclei ( green) and multiple GFAP-positive processes (red) penetrating the GCL. $b$, Confocal micrograph of BrdU-labeled GFAPpositive (arrow) and GFAP-negative cells in the SGL $72 \mathrm{hr}$ after BrdU injection. $c$, Electron micrograph of two B cells labeled with $\left[{ }^{3} \mathrm{H}\right] 2 \mathrm{hr}$ after $\left[{ }^{3} \mathrm{H}\right]$ thymidine injection. The inset shows the nuclei of these two B cells overlaid by autoradiographic silver grains in a $1.5 \mu \mathrm{m}$ section used to prepare the ultrathin section shown below. $d,\left[{ }^{3} \mathrm{H}\right]$-labeled D cell $72 \mathrm{hr}$ after $\left[{ }^{3} \mathrm{H}\right]$ thymidine injection. Note the dark cytoplasm of D cells in contrast to the light cytoplasm of B cells. The inset shows the nuclei of the $\mathrm{D}$ cell overlaid by autoradiographic silver grains in a $1.5 \mu \mathrm{m}$ section used to prepare the ultrathin section shown below. $e$, Percentage of BrdU-labeled cells in the SGL 2, 24, and $72 \mathrm{hr}$ after BrdU injection. This analysis was done at the confocal microscope; 108 cells in three animals were analyzed for each survival group. $f$, Percentage of $\left[{ }^{3} \mathrm{H}\right]$-labeled cells in the SGL 2, 24, and $72 \mathrm{hr}$ after $\left[{ }^{3} \mathrm{H}\right]$ thymidine injection; 25 cells in three animals were studied at the electron microscope for each survival group. In $e$ and $f$, error bars indicate SD. Scale bars: $a, b, 5$ $\mu \mathrm{m} ; c, 3.6 \mu \mathrm{m} ; d, 2 \mu \mathrm{m}$. cells in the SGL were also stained with antibodies to vimentin and S100 (data not shown). At this survival time, no BrdU-labeled cells were stained with antibodies to neuronal markers Tuj1 or NeuN. Many of the double-labeled BrdU-GFAP-positive cells had processes oriented radially into the blades of the dentate gyrus. Confocal microscopy, however, does not allow for the identification of cell membranes, and it was possible that some of these putative double-labeled cells corresponded to small BrdUpositive cells closely associated to neighboring GFAP-positive processes emanating from neighboring cells. To confirm that GFAP-labeled processes corresponded to the nuclei of dividing cells, we used $\left[{ }^{3} \mathrm{H}\right]$ thymidine and post-embedding GFAP immunoelectron microscopy, following the same injection protocol as for the BrdU labeling. This analysis confirmed that many of the $\left[{ }^{3} \mathrm{H}\right]$-labeled cells were GFAP positive and allowed us to describe the ultrastructure of the dividing cells in this region (Fig. 1c,d). Under the electron microscope, GFAP-positive cells had the characteristics of astrocytes: light cytoplasm containing few ribosomes, intermediate filaments, and irregular contours with plasma membrane and processes that intercalated between adjoining cells. The nuclei of these cells generally contained lax chromatin in granules, but differences in heterochromatin aggregation were noted suggesting, that the cells were in different stages of the cell cycle. In addition to labeled astrocytes, there were $\left[{ }^{3} \mathrm{H}\right]$-labeled darker cells that were GFAP negative. These darker cells were clearly different from astrocytes: they had smooth contours, dark scant cytoplasm with many ribosomes, and darker nuclei (Fig. 1d). The light astrocytic cells share ultrastructural similarities with type B cells in the SVZ (Doetsch et al., 1997); thus, we will refer to them as SGL B cells. The darker cells did not have a clear homolog in the SVZ; thus, we will refer to them as D cells.

Using confocal microscopy, we quantified the number of BrdUlabeled cells that were GFAP positive at 2,24 , and $72 \mathrm{hr}$. Inde- 

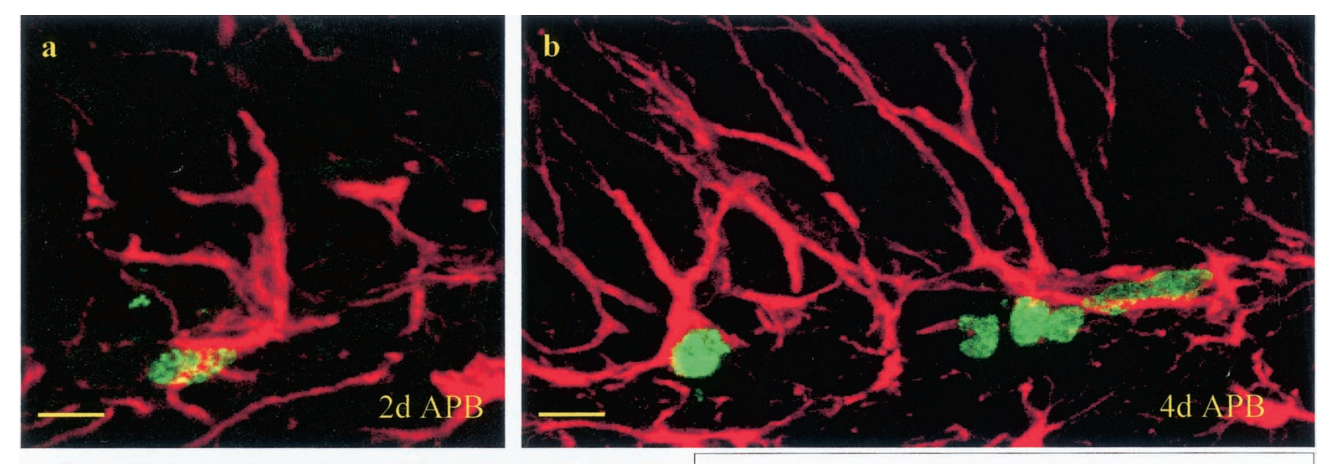

Figure 2. Cell reappearance after APB treatment. $a$, Cell labeled with BrdU (green) and GFAP (red) 2 d after termination of APB. $b$, Four days after APB, BrdU-GFAP-labeled cells remained, but some GFAP-negative BrdU-labeled cells were also present. $c$, Ultrastructural analysis of a $\left[{ }^{3} \mathrm{H}\right]-$ labeled cell (see autoradiogram in the inset) $2 \mathrm{hr}$ after $\left[{ }^{3} \mathrm{H}\right]$ thymidine injection and $2 \mathrm{~d}$ after termination of APB treatment. This cell corresponds to a $B$ cell. Note the light cytoplasm and irregular contours of the plasma membrane. $d$, Time course of reappearance of BrdU-labeled cells after termination of APB treatment; $n=5$; mean \pm SD. $e$, Cellular composition (EM) of the SGL at multiple survivals after APB termination; $n=3 ; 250$ cells per animal; mean \pm SD. Scale bars: $a, b, 8$ $\mu \mathrm{m} ; c, 2 \mu \mathrm{m}$.
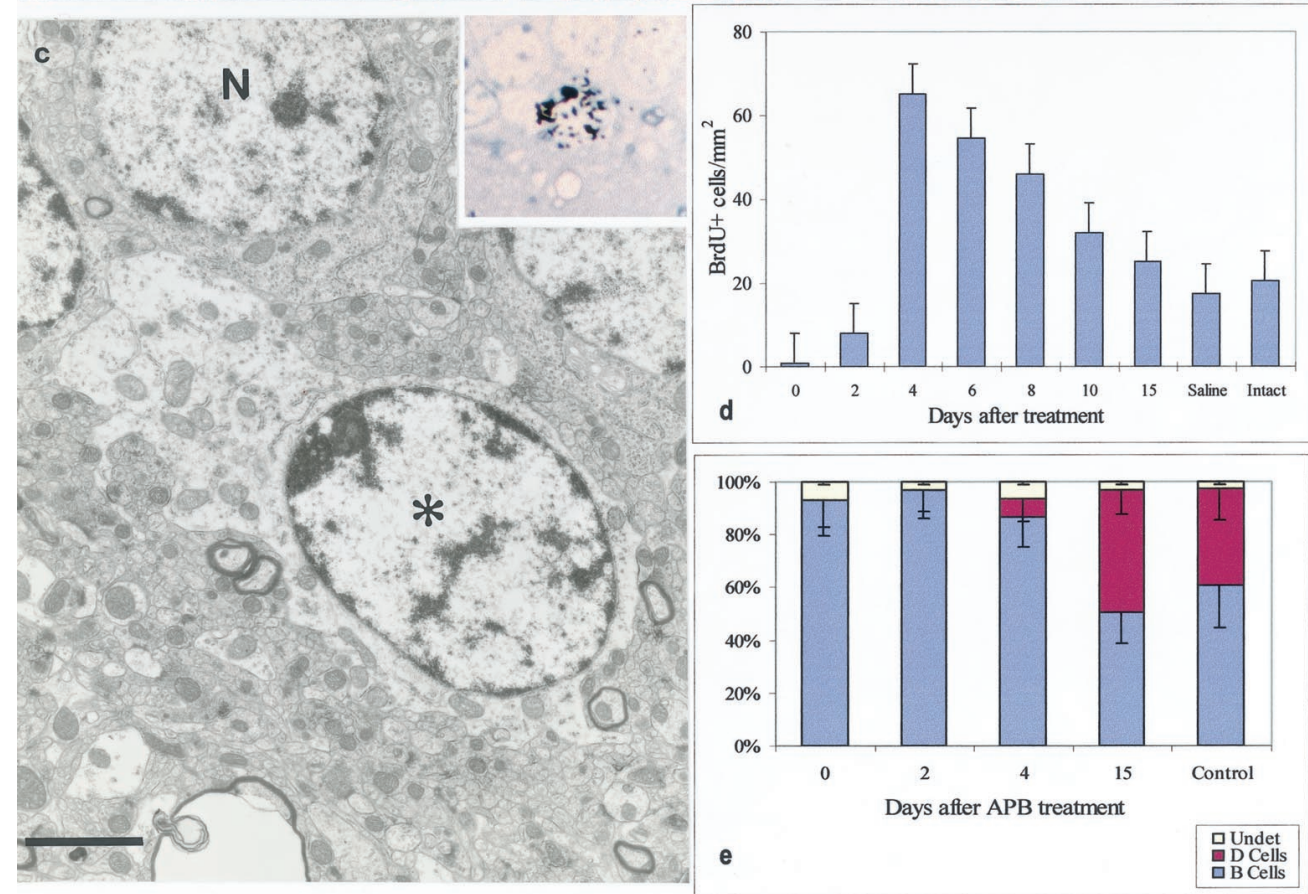

e pendently, we determined under the electron microscope the number of B and D cells labeled with $\left[{ }^{3} \mathrm{H}\right]$ thymidine at the same survivals. Results are shown in Figure 1, $e$ and $f$. Both analyses showed that, at $2 \mathrm{hr}$, more than one-half of the dividing cells corresponded to GFAP positive cells or B cells. Between 2 and 24 $\mathrm{hr}$, there was a marked reduction in the number of GFAP-positive (confocal) or labeled B (electron microscope) cells. This suggested that B cells died or gave rise to another cell type during this period. The EM analysis showed that many of the labeled cells appearing at 24 and $72 \mathrm{hr}$ after $\left[{ }^{3} \mathrm{H}\right]$ thymidine corresponded to $\mathrm{D}$ cells (Fig. $1 d, f)$.

\section{Anti-mitotic treatment}

The short-term labeling analysis indicates that there are two types of mitotically active SGL cells: type B and D cells. To determine the origins of the different dividing cells, we transiently killed actively dividing cells in this region and determined the order of appearance of the different cell types. We reasoned that, after anti-mitotic treatment, secondary precursors would only appear after the division of the primary ones. A combination of AraC administered below the meninges (Doetsch et al., 1999a) and procarbazol in the drinking water (APB treatment) for $7 \mathrm{~d}$ resulted in the elimination of most dividing cells in the SGL of the dentate gyrus (Fig. 2a). Animals in groups of five were killed at $2,4,6,8,10$, and $15 \mathrm{~d}$ after the termination of the anti-mitotic treatment. As shown in Figure $2 d$, proliferation in the SGL is reestablished after termination of the anti-mitotic treatment. By day 2, a few BrdU-labeled cells were detected, and their number increased by day 4. Fifteen days after APB termination, the number of BrdU-labeled cells had returned to levels similar to those found in saline-treated controls. We serially sectioned a region of the SGL and determined its composition at the electron microscope at 0, 2, 4, and $15 \mathrm{~d}$ after termination of APB.

Results are shown in Figure $2 e$. Ninety three percent $(n=212$ cells) of the cells analyzed in the SGL at $0 \mathrm{~d}$ and $91 \%(n=281)$ at $2 \mathrm{~d}$ after termination of APB could be identified as type B cells. Seven and $9 \%$ of the labeled cells at 0 and $2 \mathrm{~d}$, respectively, had very little cytoplasm on the sections studied and could not be identified. No D cells were detected in the SGL at these survivals. In contrast, by $4 \mathrm{~d}$, type $\mathrm{D}$ cells had reappeared, and by $15 \mathrm{~d}$ the proportion of type D cells was similar to that of controls (Fig. $2 d$ ). As mentioned above, there are a few cells labeled with BrdU or $\left[{ }^{3} \mathrm{H}\right]$ thymidine $2 \mathrm{~d}$ after termination of APB treatment. We studied these cells after staining sections with antibodies to GFAP or after processing them for EM. All of the cells studies at the electron microscope (20 cells) corresponded to B cells (Fig. $2 c$ ). Of 95 cells observed at the confocal microscope, 83 were GFAP positive (Fig. 2a). By 4 d, many of the BrdU-positive cells were not stained for GFAP (Fig. 2b). This suggests that, after termination of the anti-mitotic treatment, the division of $\mathrm{B}$ cells regenerated D cells. When animals were injected with $\left[{ }^{3} \mathrm{H}\right]$ thy- 

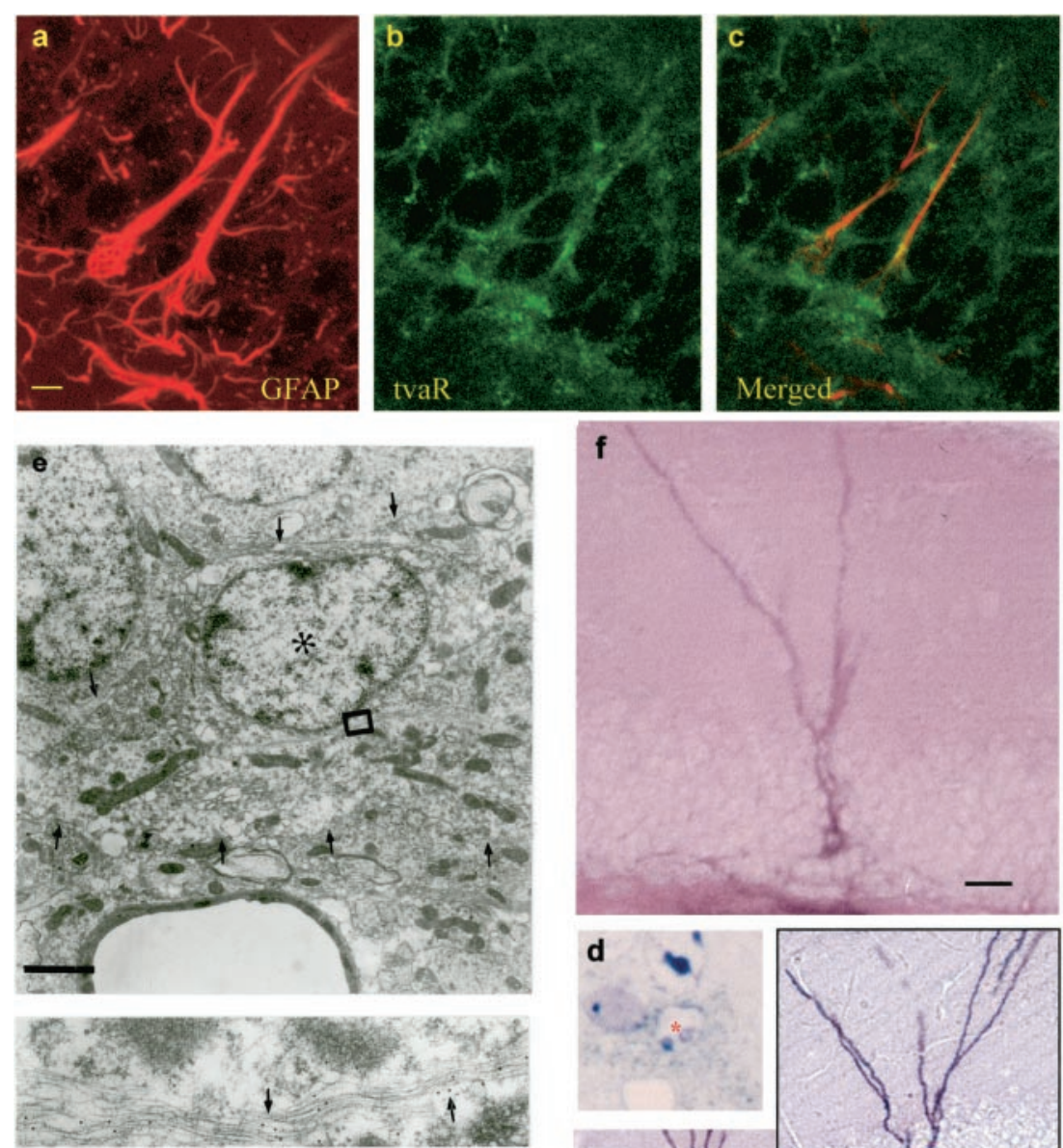

g
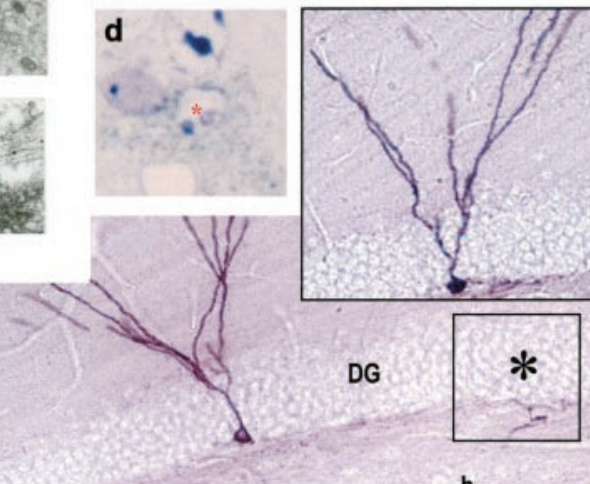

DG

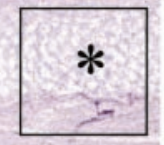

h

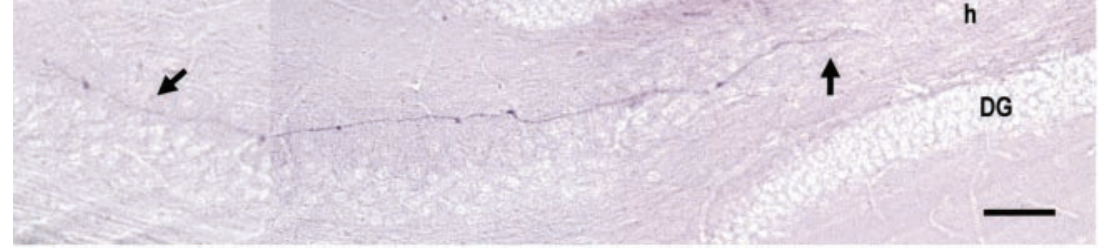

Figure 3. Retrovirally labeled SGL astrocytes give rise to new neurons in the granule cell layer. Double staining for GFAP and tvaR in the SGL of normal Gtva mice $(a-c) . a$, Staining for GFAP. $b$, Staining for the tvaR. $c$, Merged fields showing combined immunostaining for GFAP and the tvaR. AP-positive cells identified after injection of RCAS-AP virus into the dentate gyrus of Gtva mice in $e$ and $d 2 \mathrm{~d}$ after viral injection cells were analyzed at the electron microscope. $d$, Plastic section $(1.5 \mu \mathrm{m})$ of an AP-positive cell (asterisk) stained with NBT-BCIP ( purple deposit; bright field). The cell was reembedded, resectioned, and stained with goldconjugated antibodies to GFAP for ultrastructural analysis (e). Labeled cell corresponded to a B cell that contained intermediate filaments decorated by gold particles (arrows in the inset below). The arrowheads in $e$ show the irregular contours of the plasma membrane of this cell. $f$, Immature granule neurons start appearing $8 \mathrm{~d}$ after viral injection. $g$, Thirty days after RCAS-AP injection into SGL of Gtva mice, AP-labeled granule neurons are present in the dentate gyrus. These cells have the characteristic dendritic arbors in the molecular layer and an axon (arrows) that projects to CA3. The cell in the inset gives rise to the mossy fiber shown in $g$. This cell body is in the adjoining section in the approximate location shown by the asterisk. Scale bars: $a, 5 \mu \mathrm{m}$ (for $a-c) ; e, 2 \mu \mathrm{m} ; f, 10 \mu \mathrm{m} ; g, 100 \mu \mathrm{m}$. midine $2 \mathrm{~d}$ after the termination of APB treatment and allowed to survive for 5 months, fully differentiated labeled neurons were observed in the granule cell layer (GCL) of the dentate gyrus. Furthermore, labeled astrocytes were observed in the SGL after similar survival times. This long-term survival experiment suggests that the B cells dividing $2 \mathrm{~d}$ after APB termination gave rise to new neurons. The earlier appearance of type D cells suggests that these cells may function as transient precursors in the formation of new neurons.

\section{Retroviral injections}

The above results with the anti-mitotic treatment suggest that SGL astrocytes function as the primary precursors in the dentate gyrus. To directly show that GFAP-expressing cells in the SGL function as neuronal precursors in animals not exposed to APB, we used transgenic mice (Gtva) expressing the receptor (tva) of the RCAS avian leukosis virus under the GFAP promoter (Hol- land and Varmus, 1998). Previous work has shown that infection of Gtva mice with the avian leukosis virus (RCAS) carrying a reporter gene results in the labeling of GFAP-positive astrocytes (Holland and Varmus, 1998). Because the retrovirus integrates into DNA, the progeny of infected astrocytes can then be followed. When avian RCAS virus carrying the alkaline phosphatase reporter gene (RCAS-AP) was injected into the dentate gyrus of adult Gtva mice, a subset of cells in the SGL became infected. It took $\sim 2 \mathrm{~d}$ for AP-labeled cells to appear in the SGL. This is likely attributable to the time it takes for the cells to divide and accumulate enough AP protein to be detectable. We analyzed by light microscopy 20 AP-labeled cells in $2 \mu \mathrm{m}$ sections $2 \mathrm{~d}$ after infection. These cells were then analyzed by postembedding gold immunocytochemistry for GFAP at the electron microscope. All AP-labeled cells had characteristics of SGL type $\mathrm{B}$ cells (Fig. 3d,e). Similarly, most cells analyzed at the confocal 
Table 1. Cell types generated after RCAS-AP infection

\begin{tabular}{llclll} 
& $\begin{array}{l}2 \mathrm{~d} \\
(n=8)\end{array}$ & $\begin{array}{l}4-8 \mathrm{~d} \\
(n=8)\end{array}$ & $\begin{array}{l}15 \mathrm{~d} \\
(n=10)\end{array}$ & $\begin{array}{l}21 \mathrm{~d} \\
(n=12)\end{array}$ & $\begin{array}{l}30+\mathrm{d} \\
(n=17)\end{array}$ \\
\hline Astrocytes & 37 & 37 & 31 & 20 & 54 \\
Neurons & 0 & 0 & $4^{*}$ & 15 & 35 \\
Unidentified & 8 & 0 & 4 & 1 & 2
\end{tabular}

* indicates first immature neuronal figures seen in the SGL-GCL border. See Results for details. $n$, Number of brains analyzed. Both hemispheres were injected with the virus and were included in the quantification.

microscope $2 \mathrm{~d}$ after infection were double labeled for GFAP and AP (data not shown), although a few cells could not be identified. These results support the notion that astrocytes are the target of RCAS infection in the Gtva transgenic mice (Holland and Varmus, 1998). However, because by $2 \mathrm{~d}$ after infection some cells may have began their transformation, it is not possible by this approach alone to define which cells were initially targeted. To further confirm that the RCAS virus infected GFAP-positive astrocytes in the Gtva mice, we performed double immunocytochemistry for GFAP and the receptor for the RCAS virus, tvaR. A confocal analysis of tissue sections from Gtva mice further confirmed that tvaR is expressed in GFAP-positive cells with the morphology of SGL astrocytes (Fig. 3a-c).

Studying AP-positive cells at different survivals allowed us to follow the formation and maturation of new granule neurons from RCAS-AP-infected cells in the SGL (Table 1). The first immature neurons were observed $8 \mathrm{~d}$ after retroviral injection. They had a round cell body, were located in the interface between the SGL and the GCL, and projected a single dendrite through the GCL that branched in the molecular layer (Fig. $3 f$ ). Fifteen days after infection, the cell body became larger and more spherical, and the primary dendrite was more developed and arborized (Table 1). Thirty days after injection, fully mature AP-labeled granule cells were observed in the dentate gyrus (Fig. $3 g$ ). The AP staining clearly shows the morphology of these cells, with a round or oval cell body and an apical branched dendrite. Axons (mossy fibers) that originated from AP-positive cells in the dentate gyrus and that projected to the CA3 region of the hippocampus were also observed (Fig. $3 g$, inset and arrows). This characteristic identifies these cells as newly formed granule neurons. The majority of AP-labeled granule cells were observed in the granular cell layer close to the SGL-GCL border. Labeled granule neurons were frequently found in clusters of two or three cells. Astrocytes were also seen in the hilus and SGL after $30 \mathrm{~d}$ survivals.

\section{DISCUSSION}

The cells we identify here as primary precursors for new neurons in the adult hippocampus have the characteristics of astrocytes at the light and electron microscope. They contain multiple processes with intermediate filaments rich in GFAP. Results from three independent experiments support this conclusion. First, many proliferating SGL astrocytes rapidly convert to a cell type that is GFAP negative and that possesses characteristics of D cells. Second, anti-mitotic treatment resulted in the elimination of $\mathrm{D}$ cells from the SGL, but neurogenesis returned. Because new neurons are born at a time when $\left[{ }^{3} \mathrm{H}\right]$ thymidine-labeled astrocytes were observed, we infer that astrocytes function as primary precursors. Finally, we show that SGL astrocytes, specifically labeled with an avian retrovirus, give rise to granule neurons. We observed granule neurons at different stages of maturation by killing animals at different survivals after retroviral infection. Some SGL astrocytes remain labeled with thymidine analogs after prolonged periods of time (Cameron et al., 1993; present results), which suggests that some, or all, of the precursor astrocytes in the SGL may divide asymmetrically, with one daughter cell remaining as an astrocyte and the other daughter cell going on to generate a neuronal progeny. This is consistent with the behavior of stem cells in other organs (Potten and Loeffler, 1990). However, it is also possible that some astrocytes may divide symmetrically to generate two astrocytes, whereas neighboring astrocytes may have divided symmetrically to generate the neuronal progeny. Both modes of cell division would renew the neural stem cell pool within the SGL.

The appearance of small electron-dense cells (D cells) after division of SGL astrocytes suggests that SGL astrocytes may not give rise to new neurons directly. Our data show that, $2 \mathrm{~d}$ after termination of APB treatment, the vast majority $(>90 \%)$ of dividing SGL cells correspond to astrocytes and that some of these cells give rise to neurons. We do not know, however, how many times the precursor cells divided before final differentiation into neurons. D cells may serve as transient precursors, because these cells appear in the SGL between 2 and $15 \mathrm{~d}$ after APB, just after astrocytes divided and before new neurons appear. After $\left[{ }^{3} \mathrm{H}\right]$ thymidine treatment, labeled type $\mathrm{D}$ cells are frequently localized adjacent to labeled astrocytes at the base of the granule cell layer. Moreover, D cells are frequently in contact with granule neurons at the interface between the SGL and the granule cell layer at which new neurons appear. It is therefore likely that D cells function as a transient precursor in the formation of new granule neurons. This interpretation is consistent with a previous report suggesting that small, electron-dense cells, similar to the D cells described here, serve as neuronal precursors (Kaplan and Bell, 1984). However, the present work indicates that these cells are not primary precursors but are derived from dividing SGL astrocytes. Unlike the SVZ, in which intermediate precursors (type C cells) are large and highly mitotic (Doetsch et al., 1997), $\mathrm{D}$ cells in the SGL are small and do not seem to divide as frequently. This suggests that the amplification for neuronal production by transient precursors in the SGL is probably limited. Although the above data suggests that D cells function as transient precursors in the formation of new neurons, there is no direct experimental proof for this claim. The data presented here does not preclude the possibility that astrocytes could directly give rise to granule neurons without passing through the $\mathrm{D}$ cell intermediate. To properly answer this lineage question, specific markers to label D cells and methods to directly visualize the conversion from astrocytes to neurons are required.

The complex morphology of the SGL astrocytes with multiple processes that penetrate the granule cell layer (Kosaka and Hama, 1986; Eckenhoff and Rakic, 1989; Cameron et al., 1993) goes against the notion that neural progenitor cells are undifferentiated with no other role than the generation of new neurons. SGL astrocytes seem to combine functions of both progenitors and glial cells. The radial processes of SGL astrocytes that intercalate among mature granule neurons could potentially carry information from the compartment in which mature neurons reside to the germinal layer in which new neurons are born. This information could influence the proliferation and differentiation of precursors in the SGL. The elaborate structure of SGL astrocytes suggests that these neuronal progenitors play structural and chemical roles ascribed to glial cells of the dentate gyrus. Either cells that have been considered "glial cells" (Barres, 1999) have 
the potential to dedifferentiate and function as neural stem cells, or some "glial cells" are not terminally differentiated and may be more closely associated to the stem cell lineage than previously thought.

Astrocytes are derived from radial glia during fetal and early postnatal development (Levitt and Rakic, 1980; Eckenhoff and Rakic, 1989; Voigt, 1989). Both SGL astrocytes (present study) and SVZ astrocytes (Doetsch et al., 1999b) may maintain their neurogenic potential because of their derivation from radial glia. In some vertebrate species, radial glia persist in the adult brain (Horstmann, 1954; Stevenson and Yoon, 1982; Alvarez-Buylla and Nottebohm, 1988, 1995), and, in songbirds, they divide and appear to function as the primary precursors for the continual generation of new neurons (Alvarez-Buylla and Nottebohm, 1988; Alvarez-Buylla et al., 1988, 1998). Retroviral labeling experiments in the developing avian brain is consistent with the proposition that radial glia could function as neuronal precursors also during development (Gray and Sanes, 1992). In mammals, they have been generally considered committed progenitors of astrocytes (Schmechel and Rakic, 1979), but recent evidence in the developing mammalian brain indicates that radial glia can give rise to new neurons and may correspond to neural stem cells (Gaiano et al., 2000; Malatesta et al., 2000; Noctor et al., 2001). Therefore, neural stem cells are probably contained within the lineage: "neuroepithelium-radial glia-astrocytes" (Alvarez-Buylla et al., 2001). This hypothesis is particularly appealing for SGL astrocytes, because their origin from radial glia has been elegantly illustrated in the developing primate brain (Eckenhoff and Rakic, 1989).

Our findings demonstrate that new neurons in the adult hippocampus originate from astrocytes. It is important to note that neural stem cells may also reside in non-neurogenic regions of the adult brain (Weiss et al., 1996; Palmer et al., 1997, 1999). Thus, subsets of astrocytes in other brain regions may also, under appropriate conditions, function as neural precursors. The identification of astrocytes with neural stem cell potential and the regulatory mechanisms that allow them to behave as neuronal precursors will have powerful implications for the experimental manipulation of adult neurogenesis and its future use in therapeutic neuronal replacement.

\section{REFERENCES}

Altman J (1969) Autoradiographic and histological studies of postnatal neurogenesis. IV. Cell proliferation and migration in the anterior forebrain, with special reference to persisting neurogenesis in the olfactory bulb. J Comp Neurol 137:433-458.

Altman J, Das GD (1965) Autoradiographic and histological evidence of postnatal hippocampal neurogenesis in rats. J Comp Neurol 124:319-336.

Altman J, Das GD (1966) Autoradiographic and histological studies of postnatal neurogenesis. I. A longitudinal investigation of the kinetics, migration and transformation of cells incorporating tritiated thymidine in neonate rats, with special reference to postnatal neurogenesis in some brain regions. J Comp Neurol 126:337-390.

Alvarez-Buylla A, Nottebohm F (1988) Migration of young neurons in adult avian brain. Nature 335:353-354.

Alvarez-Buylla A, Theelen M, Nottebohm F (1988) Birth of projection neurons in the higher vocal center of the canary forebrain before, during, and after song learning. Proc Natl Acad Sci USA 85:8722-8726.

Alvarez-Buylla A, García-Verdugo JM, Mateo A, Merchant-Larios H (1998) Primary neural precursors and intermitotic nuclear migration in the ventricular zone of adult canaries. J Neurosci 18:1020-1037.

Alvarez-Buylla A, Garcia-Verdugo JM, Tramontin AD (2001) A unified hypothesis on the lineage of neural stem cells. Nat Rev Neurosci 2:287-293.

Barnea A, Nottebohm F (1994) Seasonal recruitment of hippocampal neurons in adult free-ranging black-capped chickadees. Proc Natl Acad Sci USA 91:11217-11221.
Barnea A, Nottebohm F (1995) Patterns of food storing by black-capped chickadees suggest a mnemonic hypothesis. Anim Behav 49:1161-1176. Barres BA (1999) A new role for glia: generation of neurons! Cell 97:667-670.

Cameron HA, Wooley CS, McEwen BS, Gould E (1993) Differentiation of newly born neuron and glia in the dentate gyrus of the adult rat. Neuroscience 56:337-344.

Chiasson BJ, Tropepe V, Morshead CM, Van der Kooy D (1999) Adult mammalian forebrain ependymal and subependymal cells demonstrate proliferative potential, but only subependymal cells have neural stem cell characteristics. J Neurosci 19:4462-4471.

Doetsch F, Garcia-Verdugo JM, Alvarez-Buylla A (1997) Cellular composition and three-dimensional organization of the subventricular germinal zone in the adult mammalian brain. J Neurosci 17:5046-5061.

Doetsch F, Garcia-Verdugo JM, Alvarez-Buylla A (1999a) Regeneration of a germinal layer in the adult mammalian brain. Proc Natl Acad Sci USA 96:11619-11624.

Doetsch F, Caille I, Lim DA, García-Verdugo JM, Alvarez-Buylla A (1999b) Subventricular zone astrocytes are neural stem cells in the adult mammalian Brain. Cell 97:1-20.

Eckenhoff MF, Rakic P (1989) Radial organization of the hippocampal dentate gyrus: a Golgy, ultrastructural, and immunocitochemical analysis in the developing rhesus monkey. J Comp Neurol 223:1-21.

Eisch AJ, Barrot M, Schad CA, Self DW, Nestler EJ (2000) Opiates inhibit neurogenesis in the adult rat hippocampus. Proc Natl Acad Sci USA 97:7579-7584.

Eriksson PS, Perfilieva E, Bjork-Eriksson T, Alborn A, Nordborg C, Peterson DA, Gage FH (1998) Neurogenesis in the adult human hippocampus. Nat Med 4:1313-1317.

Gage FH, Ray J, Fisher LJ (1995) Isolation, characterization, and use of stem cells from the CNS. Annu Rev Neurosci 18:159-192.

Gaiano N, Nye JS, Fishell G (2000) Radial glial identity is promoted by notch1 signaling in the murine forebrain. Neuron 26:395-404.

Garcia-Verdugo JM, Llahi S, Ferrer I, Lopez-Garcia C (1989) Postnatal neurogenesis in the olfactory bulbs of a lizard. A tritiated thymidine autoradiographic study. Neurosci Lett 98:247-252.

Goldman SA, Nottebohm F (1983) Neuronal production, migration, and differentiation in a vocal control nucleus of the adult female canary brain. Proc Natl Acad Sci USA 80:2390-2394.

Gould E, Cameron HA, Daniels DC, Wooley CS, McEwen BS (1992) Adrenal hormones suppress cell division in the adult rat dentate gyrus. J Neurosci 12:3642-3650.

Gould E, McEwen BS, Tanapat P, Galea LAM, Fuchs E (1997) Neurogenesis in the dentate gyrus of the adult tree shrew is regulated by psychosocial stress and NMDA receptor activation. J Neurosci 17:2492-2498.

Gould E, Beylin A, Tanapat P, Reeves A, Shors TJ (1999) Learning enhances adult neurogenesis in the hippocampal formation. Nat Neurosci 2:260-265.

Gray GE, Sanes JR (1992) Lineage of radial glia in the chicken optic tectum. Development 114:271-283.

Holland EC, Varmus HE (1998) Basic fibroblast growth factor induces cell migration and proliferation after glia-specific gene transfer in mice. Proc Natl Acad Sci USA 95:1218-1223.

Horstmann E (1954) Die Faserglia des Selachiergehirns. Z Zellforsch 39:588-617.

Johansson CB, Momma S, Clarke DL, Risling M, Lendahl U, Frisén J (1999) Identification of a neural stem cell in the adult mammalian central nervous system. Cell 96:25-34.

Kaplan M, Bell D (1984) Mitotic neuroblasts in the 9 day old and 11 month old rodent hippocampus. J Neurosci 4:1429-1441.

Kaplan MS, Hinds JW (1977) Neurogenesis in the adult rat: electron microscopic analysis of light radioautographs. Science 197:1092-1094.

Kempermann G, Kuhn HG, Gage FH (1997) More hippocampal neurons in adult mice living in an enriched environment. Nature 386:493-495.

Kosaka T, Hama K (1986) Three-dimensional structure of astrocytes in the rat dentate gyrus. J Comp Neurol 249:242-260.

Laywell ED, Rakic P, Kukekov VG, Holland EC, Steindler D (2000) Identification of a multipotent astrocytic stem cell in the immature and adult mouse brain. Proc Natl Acad Sci USA 97:13883-13888.

Levitt P, Rakic P (1980) Immunoperoxidase localization of glial fibrillary acidic protein in radial glial cells and astrocytes of the developing rhesus monkey brain. J Comp Neurol 193:815-840.

Lim DA, Tramontin AD, Trevejo JM, Herrera DG, Garcia-Verdugo JM, Alvarez-Buylla A (2000) Noggin antagonizes BMP signaling to create a niche for adult neurogenesis. Neuron 28:713-726.

Lois C, Alvarez-Buylla A (1993) Proliferating subventricular zone cells in the adult mammalian forebrain can differentiate into neurons and glia. Proc Natl Acad Sci USA 90:2074-2077.

Lois C, Alvarez-Buylla A (1994) Long-distance neuronal migration in the adult mammalian brain. Science 264:1145-1148.

Lopez-Garcia C (1993) Postnatal neurogenesis and regeneration in the lizard cerebral cortex. In: Neuronal cell death and repair (Cuello C, ed), pp 237-246. Amsterdam: Elsevier. 
Malatesta P, Hartfuss E, Götz M (2000) Isolation of radial glial cells by fluorescent-activated cell sorting reveals a neuronal lineage. Development 127:5253-5263.

Markakis EA, Gage FH (1999) Adult-generated neurons in the dentate gyrus send axonal projections to field $\mathrm{CA} 3$ and are surrounded by synaptic vesicles. J Comp Neurol 406:449-460.

Morshead CM, Reynolds BA, Craig CG, McBurney MW, Staines WA, Morassutti D, Weiss S, Van der Kooy D (1994) Neural stem cells in the adult mammalian forebrain: a relatively quiescent subpopulation of subependymal cells. Neuron 13:1071-1082.

Noctor SC, Flint AC, Weissman TA, Dammerman RS, Kriegstein AR (2001) Neurons derived from radial glial cells establish radial units in neocortex. Nature 409:714-720.

Palmer TD, Takahashi J, Gage FH (1997) The adult rat hippocampus contains primordial neural stem cells. Mol Cell Neurosci 8:389-404.

Palmer TD, Markakis EA, Willhoite AR, Safar F, Gage FH (1999) Fibroblast growth factor-2 activates a latent neurogenic program in neural stem cells from diverse regions of the adult CNS. J Neurosci 19:8487-8497.

Palmer TD, Willhoite AR, Gage FH (2000) Vascular niche for adult hippocampal neurogenesis. J Comp Neurol 425:479-494.

Parent JM, Yu TW, Leibowitz RT, Geschwind DH, Sloviter RS, Lowenstein DH (1997) Dentate granule cell neurogenesis is increased by seizures and contributes to aberrant network reorganization in the adult rat hippocampus. J Neurosci 17:3727-3738.
Potten CS, Loeffler M (1990) Stem cells: attributes, cycles, spirals, pitfalls and uncertainties lessons for and from the crypt. Development 110:1001-1020

Roy NS, Wang S, Jiang L, Kang J, Benraiss A, Harrison-Restelli C, Fraser RA, Couldwell WT, Kawaguchi A, Okano H, Nedergaard M, Goldman SA (2000) In vitro neurogenesis by progenitor cells isolated from the adult human hippocampus. Nat Med 6:271-277.

Schmechel DE, Rakic P (1979) Arrested proliferation of radial glial cells during midgestation in rhesus monkey. Nature 277:303-305.

Shors TJ, Miesegaes G, Beylin A, Zhao M, Rydel TGE (2001) Neurogenesis in the adult is involved in the formation of trace memories. Nature 410:372-376.

Stanfield BB, Trice JE (1988) Evidence that granule cells generated in the dentate gyrus of adult rats extend axonal projections. Exp Brain Res 72:399-406.

Stevenson JA, Yoon MG (1982) Morphology of radial glia, ependymal cells, and periventricular neurons in the optic tectum of goldfish (Carassius auratus). J Comp Neurol 205:128-138.

Voigt T (1989) Development of glial cells in the cerebral wall of ferrets: Direct tracing of their transformation from radial glia into astrocytes. J Comp Neurol 289:74-88.

Weiss S, Dunne C, Hewson J, Wohl C, Wheatley M, Peterson AC, Reynolds BA (1996) Multipotent CNS stem cells are present in the adult mammalian spinal cord and ventricular neuroaxis. J Neurosci 16:7599-7609. 